\title{
COMMUNICATIONS
}

\section{SOME REMARKS UPON SPRING CATARRH: WITH SPECIAL REFERENCE TO ITS DIAGNOSIS AND ITS TREATMENT WITH RADIUM *}

BY

\author{
T. Harrison Butler, M.D. Oxon.,
} LEAMINGTON SPA, ENGLAND.

My excuse for addressing you upon such a comparatively ordinary subject as spring catarrh is twofold: I have noted that many experienced ophthalmic surgeons rather hesitate to make a definite diagnosis in these cases, when the signs are not absolutely typical ; and that they do not all yet fully realise that in radium a specific form of treatment has been found for a disease which, up to the present, has resisted all other methods.

Spring catarrh is not common in the British Isles. I see one new case about every two years, an incidence of about 1 in 10,000 new cases. It is not, however, as rare as has been supposed, for it is almost certain that some slight and atypical examples are overlooked.

I do not propose to say anything about the histology and pathology of the disease, for all that is known is contained in the text-books. I must, however, draw your attention to the constant presence of a large number of eosinophil cells in the secretion from the conjunctiva, and to the slight but definite increase of these cells in the blood. In consequence, an examination of a smear from the conjunctiva will, in a doubtful case, at once settle the diagnosis. A simple method is to fix the slide with alcohol and ether, and to stain with eosin. If there be no excess of eosinophil cells, the disease is not spring catarrh. I have never yet failed to find the cells in true examples of the disease, and doubtful cases which did not contain eosinophil cells in the secretion have invariably proved to be affected with some other disease.

Spring catarrh appears in three forms: the palpebral, the circumcorneal, and the mixed.

The clinical features of the disease are so characteristic that a surgeon who has once seen a typical case should never fail to recognize it. The reverse mistake, to confuse an atypical example of phlyctenular conjunctivitis with spring catarrh is possible, but an examination of the conjunctival secretion will at once clear up any doubt.

*An address to the Oxford Ophthalmological Congress, July, 1916. 
Quite recently I admitted a case of strumous conjunctivitis into my ward as an example of spring catarrh. Repeated examinations failed to discover any excess of eosinophil cells, and the subsequent history of the case made it clear that the circumcorneal elevations were of a phlyctenular nature.

The typical palpebral form of the disease is quite unlike anything else. The tarsus is covered with a regular tessellation which is dissimilar to the condition seen in trachoma. It can only be confused with trachoma when, as is not uncommon in Egypt and Palestine, the two diseases co-exist. Here again the answer of the microscope is unequivocal and final.

The course of the disease is quite different from that of trachoma. Trachoma subsides leaving a scarred lid; spring catarrh disappears and no trace of it remains.

Although in England the circumcorneal elevations never invade the central portions of the cornea, this is by no means an invariable rule in the Near East. During my four years service at the British Ophthalmic Hospital at Jerusalem I saw a large number of cases, for the disease is common there. I have photographs* of some typical and unusual cases, from some of which I have had the slides taken which I now wish to show you.

The first series was taken from a young Arab whose case was the worst which I have seen. You will note that the upper lids are covered with large nodules which take the place of the regular tessellation usually seen. The circumcorneal growth is very extensive and covers most of the cornea, leaving only a small central, more or less, clear area.

The other slides exhibit the appearances seen in typical cases, and show the characteristic tessellation of the inner aspect of the upper lid and the classical circumcorneal elevation.

In nearly all cases of spring catarrh the conjunctiva, both palpebral and limbal, has a peculiar milky appearance which, as far as I am aware, is not seen in any other disease. This sign is a useful aid to diagnosis.

Until the action of radium had been discovered, we were able to do little for these patients. They were treated with yellow oxide of mercury, with adrenalin, with dionin and with a host of other agents, without influencing the disease. In time the disease spontaneously disappeared, only to recur as soon as the hot weather again set in.

The total exclusion of air has been recommended by $\mathrm{H}$. Beyer (Bericht der Ophthalmologischen Gesellschaft, Heidelberg, 1913), who states that in his hands this method has been very valuable. I have

* These photographs were reproduced to illustrate an article upon spring catarrh which I contributed to the Lancet for November 9, 1907, and are not repeated here. 
tried it and I believe that it is helpful, but it failed to cure the cases in which I employed it.

Radium has proved to be the only successful treatment; under its action the disease rapidly improves and eventually disappears. In my cases the action has appeared to be more powerful upon the palpebral than upon the limbal form, but my experience has been too small to speak definitely upon this point.

The procedure will be best explained by an account of two cases.

Case I.-Mr. W., aged 31 years, had been living for some years in the Malay States, and when there his eyes became inflamed. $\mathrm{He}$ was treated for trachoma, but did not improve; so he returned to England for advice. His case was again diagnosed as trachoma, and was treated with copper sulphate. Later on he had his lids " expressed." Under this régime he steadily got worse.

I first saw him in September, 1913. The conjunctivæ were stained with silver salts and the inner surface of the upper lids was severely scarred by the action of forcible "expression." There was great lacrimation, itching, and photophobia.

The conjunctiva was milky and suggested spring catarrh. The upper lids showed the typical tessellation of spring catarrh. There were no circumcorneal elevations.

A diagnosis of spring catarrh was made, and this was confirmed by an examination of the conjunctival secretion which was full of eosinophil cells.

The patient was treated with adrenalin drops and with a solution of zinc sulphate in a $\frac{1}{4}$ per cent. solution. Complete exclusion of air was attained by the employment of motor goggles with a rubber inflated rim.

No material improvement resulted from this course of action.

On October 4, 1913, I sent Mr. W. to Sir James Mackenzie Davidson, who applied to each everted upper lid, for five minutes, a tube containing 45 milligrammes of radium bromide. This treatment was repeated on October 27, 1913.

The result was gratifying to all concerned. I saw Mr. W. on November 20, and found that there were no subjective symptoms at all. The lids were quite smooth, and only showed some mottling, the result of "expression."

On December 16 the radium was again applied to each lid for three minutes.

Mr. W. now returned to the East, and wrote to me that he still had inflamed eyes.

He again returned home, and came to me. I found that he now had no signs of spring catarrh, but only a chronic conjunctivitis. This has proved to be very difficult to cure. Radium was applied occasionally, but there have never been any further signs of spring catarrh. 
The troublesome conjunctivitis had been greatly benefited by the use of a solution of zinc sulphate.

$\mathrm{Mr}$. W. is now in the Army, and, as I have had no news of him for some months, I conclude that his condition has been completely cured.

In this case the use of radium at once cured a condition which had for a long time resisted all kinds of treatment. At the time when the first dose was given the patient was in a truly miserable state, but radium relieved him in a few days. $\mathrm{He}$ himself is quite enthusiastic about his cure by radium.

Case 2.-Ch. H., aged 14. First seen at the Warneford Hospital, Leamington, in May, 1910.

The lids were rough, but did not show the typical tessellation of spring catarrh. Each cornea was surrounded by a gelatinous, nodular ring of raised tissue of the kind which is characteristic of spring catarrh. The conjunctiva had a milky appearance, and the secretion contained a large number of eosinophil cells.

There had been several attacks previously. The disease tended to appear in May, lasted all the summer, and improved as soon as the cold weather set in.

Under treatment with adrenalin the eyes improved, but relapsed badly in August.

Patient came again in May, 1911, as bad as ever. In August, 1911, she was worse, and now the lids showed tessellation.

The disease reappeared every year till the present year, when I saw her at the end of January.

As soon as I could arrange an appointment, I sent her to the Radium Institute, where she was treated by Dr. J. E. A. Lynham. Two small square varnished plates were used, each containing the equivalent of 7 milligrammes of radium bromide. The applications were made as follows :-

Feb. 16.-External aspect of upper lid $\ldots 8$ minutes each

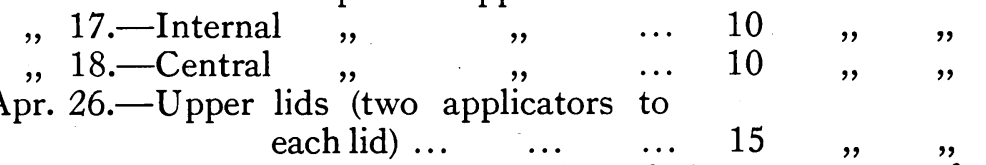

Cornea.-One applicator to each side of the upper "part of the cornea on two consecutive days-eight minutes.

Apr. 27.-The upper lids were again treated.

The effect of this treatment was not so immediate as in the case of the last patient, but when the reaction had passed off, the response was obvious.

This patient when shown to the Congress had lost all subjective symptoms. The circumcorneal elevations were much smaller, and all injection had disappeared. 
I have seen her once since, and found that she was almost well. The fact that she has not reappeared shows that, in her opinion, she is practically cured.

Sir James Mackenzie Davidson, to whom, and to Dr. J. E. A. Lynham, I am greatly obliged for full notes of the treatment, says in his letter to me:-

"I may say that in every case without exception which I have treated with radium the plaques have completely disappeared leaving no scars at all. In a few cases the eye has continued irritable and injected, but the appearances characteristic of the disease have not appeared. I look upon radium as a specific for spring catarrh."

The two foregoing cases entirely corroborate Sir James's opinion.

\section{ANOPHTHALMIA AND MICROPHTHALMIA}

BY

D. Leighton Davies, M.S., F.R.C.S.,

ASSISTANT OPHTHALMIC SURGEON, KING EDWARD VII HOSPITAL, CARDIFF.

CONGENITAL malformations have always a certain amount of interest attached to them. In many parts of the body these malformations, when they interfere with the comfort and wellbeing or the usefulness of the individual, are amenable to surgical treatment. In the case of the eyeball, however, such defects are very seldom remediable. On the other hand, in this situation they are open to very close examination, so that their interest is increased. I therefore venture to add to the already long list of congenital abnormalities, so far as it concerns our own specialized region, the following five cases :-

CASE 1.-Anophthalmia.-A. W. I first saw this child in February, 1910. She was then six weeks old, and was brought to the King Edward VII Hospital, Cardiff, on account of a thick white discharge from the right orbit. From the history obtained, the following points are worthy of note.-The child was born at term; there were other children, but the numbers were not given; none of them, however, suffered from any deformities; there had been no miscarriages. The parents were not related before marriage, and there was no history of deformities existing in the relations of either parent. The mother volunteered a statement that in the second month of her pregnancy, she had a severe fright, which she thought would account for the deformity in her baby. Otherwise she was in perfect health.

The notes of the case as then seen are as follows:-

There is a muco-purulent discharge from the right orbit, which is 